\title{
Shark Conservation - Analysis and Synthesis
}

\author{
Ila France Porcher \\ Bruz, France \\ ilafranceporcher@protonmail.com \\ ORCID \# : 0000-0003-3410-4732
}

Dr. Brian W. Darvell

Dental Materials Science, University of Birmingham, United Kingdom

ORCID \# : 0000-0003-0291-1134

Dr. Iris Ziegler

Sharkproject, Affoltern am Albis, Switzerland

\begin{abstract}
A detailed analysis of fishing records has shown that the shark species accessible to global fisheries have been systematically depleted for decades. They were already fished to about 10 percent of their former levels by 2003 . Now one species after another is being listed on the IUCN Red List of Threatened Species as their numbers drop towards extinction. Shark depletion has not been well documented and a large proportion of shark mortality has been bycatch, the target species being teleost fish. But with the rise in value of shark fins due to the shark fin trade, at the same time as teleost fish stocks have become severely overfished, sharks, along with tuna, have become the most valuable catches. Fishing on the high seas is scarcely profitable, and so is heavily supported by subsidies. But the shark fin trade, in which organized crime is heavily involved, is driven by enormous profits and provides a powerful demand for the fins of all sharks. Thus it is now being supplied by fisheries around the world. There is no interest in sustainability in consumer countries, and neither the will nor the resources to manage the trade exist. Although some shark fisheries might have been managed sustainably in some regions for certain species for meat, such fisheries are increasingly dependent on the shark fin trade.. The rising global demand for shark fins, coupled with the increasing depletion of the animals supplying that demand, makes commercial fishing for sharks unsustainable. Given their high ecological value across the aquatic ecosystems they inhabit, it is important that they receive more effective measures of protection going far beyond the currently existing ones. In particular, protection of all sharks, manta rays, devil rays and rhino rays through an Appendix I CITES listing should be effected immediately due to the scale of the global take of the shark fin trade and the state of shark depletion amply documented in the literature.
\end{abstract}

\section{Keywords}

biodiversity conservation, sharks, sustainable shark fishing, fisheries, shark fin trade

\section{Declarations:}

Funding: None.

Conflict of Interest: The authors declare that they have no conflict of interest.

Ethical approval: No animal testing was performed for this study.

Sampling and field studies: The study does not contain sampling material or data from field studies.

Data availability: Data sharing not applicable to this article; no datasets were generated or analysed.

Code availability: Not applicable

Author Contribution Statement:

IFP had the idea for the article, performed the majority of the literature search, and wrote the first draft. BWD and IZ augmented the literature, edited, and defined some themes in more detail. All three authors worked on enhancing the paper.

\section{Acknowledgments:}

We thank Alex Hofford and Keith DP Wilson for reading an early draft and making helpful suggestions. 


\section{Introduction}

Shark conservation has been the subject of numerous reports over many years, with arguments for and against action to limit the fishery. In the absence of a clear conclusion or consensus, we present here a detailed and comprehensive datadriven analysis of the various aspects of the matter.

The growing market for shark fin soup, a fashionable, high-end Chinese dish, has resulted in intensive shark fishing across all oceans, but most of the slaughter is neither recorded nor managed (Clarke et al. 2006a, b; Dulvy et al. 2008; Worm et al. 2013; Dulvy et al. 2014; Fields et al. 2017). However, sharks have low productivity, and thus a low capacity to withstand fishing mortality (Myers \& Worm 2003). As a result, their numbers are plummeting. In a rigorous global study, in 2014 Dulvy et al. found one quarter of shark and ray species to be threatened with extinction as a result of overfishing, in what could be called "a chronic accumulation of global marine extinction risk." In 2019 the UN Biodiversity Council (IPBES 2019) warned that more than one third of all known shark and ray species are facing the risk of extinction within the next decades and explicitly named commercial fishing over the last 50 years as the main reason for the loss of marine biodiversity.

As a result of the shark fin trade, and because some $90 \%$ of teleost fish stocks are over-exploited (World Bank 2017), sharks have become the most lucrative target. Consequently, fisheries that have not previously hunted them are now doing so (Clarke et al., 2007; Hareide et al. 2007; Dulvy et al. 2008). Pelagic sharks have been hardest hit (Dulvy et al. 2008; Oliver et al. 2015) and they provide most of the fins on the market (Clarke et al. 2006a, b; Fields et al. 2017). However, sharks in a wide variety of ecosystems are being targeted. In 2020, MacNeil et al. found that reef sharks are functionally extinct on $19 \%$ of coral reefs. In Southeast Asia, where large numbers of shark species evolved in its diverse, coral ecosystems, elasmobranchs are particularly threatened and overfished, yet no records have been kept, so the true extent of elasmobranch losses is unknown (Lam \& Sadovy de Mitcheson 2011).

In 2013 Worm et al. estimated that between 63 and 273 million sharks were killed each year (the uncertainty is due to whether the tonnage is made up of larger or smaller sharks). Given that reports for various regions in the world indicate that most sharks caught are immature (Ward \& Myers 2005, Lam \& Sadovy de Mitcheson 2011, Doherty et al. 2014, ICCAT 2019), it is likely that the true number was closer to the higher estimate. Currently, about 600,000 metric tonnes (t) of sharks and rays are caught each year by just the world's top 20 shark fishing nations (Okes \& Sant 2019). These figures do not account for dead discards, or the high post-release mortality resulting from poor or inadequate handling procedures (Hutchison et al. 2015) in the case of threatened species on which there is a retention ban Because sharks range far from land and migrate across oceans, outside countries' Exclusive Economic Zones (EEZs), their status is difficult for Regional Fisheries Management Organizations (RFMOs) to assess. IUCN (2019) lists 198 data deficient shark species out of 494 assessed species. Jurisdictional issues, along with the difficulties of obtaining relevant data, have long obscured understanding of their diversity and true numbers (Stevens et al. 2000). RFMOs have placed higher priority on species with greater economic importance so that shark management in general has been low priority, poor, or entirely lacking (Stevens et al. 2000; Dulvy et al. 2008; Davidson et al. 2016; Cashion et al. 2019).

In consumer countries shark fin is a luxury item and there is little interest in sustainability or legal trade. Rich consumers are willing to pay high prices while the will, oversight, and enforcement necessary to manage the trade is generally absent. Thus market demand will continue to fuel the intensive search for more sharks, and the problem is likely to become greater as scarcity forces prices up (Sadovy de Mitcheson et al. 2018). In 2016 Campana estimated the shark fin market to be worth approximately US\$350 million (Campana 2016).

Although the idea that sharks are being fished sustainably around the world is still put forward (Simpfendorfer \& Dulvy 2017; Shiffman \& Hueter 2017), in reality very few of today's commercial shark fishing operations are managed sustainably. Simpfendorfer \& Dulvy (2017) found that only a few smaller and highly productive shark species are managed sustainably, while $91.3 \%$ of shark catches are biologically unsustainable. Feretti et al (2020) found that only 16 shark fisheries globally, were well managed. Further, even in well managed shark fisheries, ecosystem impacts are almost impossible to detect, difficult to evaluate and therefore ignored in stock assessments (Ferretti et al. 2010; Travis et al. 2014). Most shark species are impossible to catch selectively (Walker 1998), especially when using longline gear, 
and therefore other shark species will be caught as bycatch, including those that are overfished, or threatened (Campana 2016).

The evidence shows that high fishing mortality has caused increasing shark depletion since industrial fishing began, and that now, with the added pressure of the shark fin trade, a large fraction of the species accessible to commercial fishing are approaching extinction. Without intervention, given the nature of the trade, the situation will continue to decline. Therefore, in the interests of averting a catastrophic collapse across the planet's diverse marine, riverine and estuarine ecosystems, sharks and their habitats must be given effective protection (IPBES 2019 ).

\section{Background}

Industrial fishing began throughout the world's tropical and temperate oceans after WWII, although some areas were being fished intensively prior to that (Myers \& Worm 2003; Ward \& Myers 2005; Ferretti et al. 2010). This pressure has only escalated (Kroogsma et al. 2018).

By 2003, the global ocean had lost an estimated $90 \%$ of its predators, $80 \%$ within the first 15 years of industrial exploitation (Myers \& Worm 2003; Ward \& Myers 2005). Though RFMOs have considered it acceptable to fish regional stocks to a low level, this was the first time that it was found that the planetary ocean as a whole had been fished to such a drastic extent: severe depletion of entire communities had occurred throughout its ecosystems.

Today, with approximately 2.9 million motorized fishing vessels hunting the global ocean, the footprint of industrial fishing exceeds other forms of food production (Kroodsma et al. 2018). Modern longliners, sea bottom and deep sea trawling, and fish aggregating devices (FADs) are particularly lethal (Jones 1992; Sumaila et al. 2010; Norse et al. 2011; Filmalter et al. 2013; Hanich et al. 2019). However, wild fisheries provide only $1.2 \%$ of global caloric production for human food consumption (Kroodsma et al. 2018).

Major shifts in biomass and size composition have occurred, and large predatory fish, such as tuna and sharks, are most affected (Ward \& Myers 2005; Myers et al. 2007; Ferretti et al. 2010). For example, the mean weight of blue sharks (Prionace glauca) caught was $52 \mathrm{~kg}$ in the 1950s, but just $22 \mathrm{~kg}$ in the 1990s, while the species abundance fell to only $13 \%$ of that of the 1950s (Ward \& Myers 2005). Over-exploitation and collapse of the porbeagle (Lamna nasus) population in the Northeast Atlantic in the 1960s led to intensive directed fishing in the Northwest Atlantic, where most of the virgin biomass was removed in just six years (Dulvy et al. 2008). A similar situation is now ongoing for the spiny dogfish (Squalus acanthias) (Fordham et al. 2016).

Sharks were always a substantial bycatch taken by longliners, drift nets, purse seine nets, and bottom trawlers. In the Atlantic Ocean, longliners caught two or three sharks for every swordfish, and in the Gulf of Mexico and Pacific Ocean one shark was caught for every two yellowfin tuna (Ferretti et al. 2010). They were mostly discarded as trash while official fisheries statistics recorded only landed catches (Campana 2016; Fordham et al. 2016).

As a result of such intensive industrial fishing, rapid and extreme declines in shark catches occurred (Ward \& Myers 2005). In the Pacific, for example, the catch of silky shark (Carcharhinus falciformis) decreased by some $92 \%$, while in the Gulf of Mexico catches of the oceanic whitetip (Carcharhinus longimanus) fell by more than $99 \%$ (Ferretti et al. 2010). Along the eastern shore of the United States of America (USA) huge declines were recorded: $87 \%$ for sandbar sharks (Carcharhinus plumbeus), 93\% for the oceanic blacktip (Carcharhinus limbatus), 97\% for tiger sharks (Galeocerdo cuvier), 98\% for scalloped hammerheads (Sphyrna lewini), and more than 99\% for bull (Carcharhinus leucas), dusky (Carcharhinus obscurus) and smooth hammerhead (Sphyrna zygaena) sharks (Myers et al. 2007). Ecologically, they were functionally removed (Heithaus et al. 2008). In the South China Sea 109 species of sharks were recorded as being fished in the 1970s but only 18 are present in current market surveys. The market is now dominated by smaller species, of which $65 \%$ are under the age of sexual maturity (Lam \& Sadovy de Mitcheson 2011). Indonesia is the largest shark fishing country in the world and its annual catch exceeds 100,000 t per year from its 17,000 islands (Sadovy de Mitcheson et al. 2018), yet fishery management is virtually absent. Japan has operated some of the largest elasmobranch fisheries in the Northwest Pacific and was already trading shark fins with China more than 200 years ago. However, Japan's large trawl fisheries showed signs of being over-exploited before World War II, so in the Northwest Pacific, shark exploitation may have peaked before the 1950s (Ferretti et al. 2010). In the Mediterranean, trawl fishing 
led to the loss of 16 out of 31 species in the Tyrrhenian Sea, 6 out of 33 species in the Adriatic Sea, and half of the species in the Gulf of Lion since the 1950s. Nine of the 16 shark species still landed in the Mediterranean are more threatened regionally than at the global level and between 53 and $71 \%$ are at risk of extinction (Cashion et al. 2019). Pelagic fisheries landings in Brazil recorded the disappearance of 14 species of carcharhinids between 1977 and 1994 (Amorim et al. 1998).

Since the 1980s, the tuna industry has increasingly made use of dFADs (Balderson \& Martin 2015) In the Indian Ocean, over $80 \%$ per cent of the purse seine catch is now made on sets around dFADs (Hanich et al. 2019). These take advantage of the tendency of tuna to shelter beneath floating objects to maximize their catch. A variety of other marine animals, including the juveniles of oceanic whitetip and silky sharks, also use that shelter.

Drifting FADs consist of floating platforms trailing lengths of netting to ensure that they move with the ocean currents, rather than being swept along by the wind. They are left to drift, usually for several months between visits by the fishing fleet, which uses purse seines to net the entire shoal of fish that has accumulated beneath them. The sharks are then either retained as bycatch or discarded depending on regional conservation measures. Overall survival rates are low (Poisson et al. 2014, Eddy et al. 2016). Hutchison et al. (2015) found that overall mortality in discarded juvenile silky sharks exceeded $84 \%$ (Hutchison et al. 2015). Half of all tuna are now caught using dFADs (Balderson \& Martin 2015) and in the Indian Ocean alone, between 480,000 and 960,000 juvenile silky sharks are killed per year through entanglement in the trailing nets (Filmalter et al. 2013). This mortality is comparable in scale to the entire reported world fishing catch of 400,000 to 2,000,000 animals; the silky shark is second only to the blue shark in the fin trade (Fields et al. 2017). Though some RFMOs are beginning to demand that dFADs must be non-entangling, the criteria for a non-entangling dFAD are weak. Many dFADs constructed to be non-entangling become entangling with the passage of time (Wang et al. 2020).

As well as the shark fin market, the increasing demand for shark liver oil, squalene, is a prominent cause of shark mortality. Squalene fishermen often extract the animal's liver and throw the body back into the ocean, which is called "shark livering." The shark liver oil market requires more than three million deep-sea sharks annually and targets species with large livers such as the Greenland shark (Somniosus microcephalus), whale shark (Rhincodon typus), and deep sea sharks including the gulper shark (Centrophorus granulosus), the leafscale gulper shark (Centrophorus squamosus) and the Portugese dogfish (Centroscymnus coelolepis). Even when they are caught in low numbers, deepsea sharks are extremely vulnerable to fishing. However, except in South Korea, there is no standard code designating this product, countries do not declare their exchanges to FAO, and it is therefore not possible to analyse the global shark liver oil market (Chabrol 2012).

Global studies of shark depletion have emphasized the problems inherent in assessing the true situation, providing detailed descriptions of the difficulties on every level (Clarke et al. 2006a, b; Worm et al. 2013; Dulvy et al. 2014; Dent \& Clarke 2015) For a shark fishery to be sustainable it must be possible to determine not only what the shark fishing mortality is, but also the mortality that will produce maximum sustainable yield, yet in the case of sharks those reference points are often not known or are extremely uncertain (Worm et al. 2013; Dulvy et al. 2014; Campana 2016; ICCAT 2019; Queiroz et al. 2019).

For example, in 2015 the International Scientific Committee for Tuna and Tuna-like Species in the North Pacific Ocean analysed shortfin mako stocks using the most complete data available. It found that due to missing information, untested indicators, and conflicts in the available data, the assessment was impossible to make at all (NOAA 2017).

Clarke et al. (2006a, b) found that the shark biomass required to support the shark fin trade annually exceeds the total catch reported to the Food and Agriculture Organization of the United Nations (FAO) (which is the only organization keeping track of catches globally) by three or four times. The inconsistent recording of shark catches and the secrecy involved in the trade in shark products makes it difficult if not outright impossible to produce proper assessments of mortality. Most shark hunting nations do not keep species-specific catch statistics (Clarke et al., 2006a, b; Musick \& Musick 2011; Dent \& Clarke 2015; Fields et al. 2017). 


\section{Shark Protection Measures}

The regulations passed to protect and manage sharks in the past decades have been ineffective in stopping the decline (Ward-Paige et al. 2012; Davidson et al. 2016), and listings by the Convention on International Trade in Endangered Species of Wild Fauna and Flora (CITES) are proving inadequate in the face of the secretive shark fin trade (Fields $e t$ al. 2017; Cardeñosa et al. 2019; Booth et al. 2020). To date, only 5 species of ray (sawfish) and not one species of shark has been listed under CITES' Appendix I in spite of their ongoing depletion, though 14 species of shark and 27 species of ray, including the IUCN critically-endangered rhino rays, have been granted listings on Appendix II. Listings are opposed by shark hunting nations because of the high commercial value of the fins (Worm et al. 2013). Protection must be gained one species at a time, while the shark fin market is indiscriminate, taking fins from essentially any species of shark or ray. Once separated from the animal, it is difficult to determine from which species a fin has been taken, so enforcement is weak (Clarke et al. 2006a). Further, an Appendix II CITES listing only requires a "Non-detrimental" finding to export fins from the listed species-it grants no protection from being fished in the first place. Since fins can be stockpiled until a "Non-detrimental" finding can be arranged, under the influence of the shark fin trade the loophole undermines the protection that was intended by the original CITES listing (CREMA 2018).

The whale shark continues to decline in both abundance and size in spite of being protected by the Bonn Convention on Migratory Species of Wild Animals 2010 (CMS), CITES, and the Commonwealth Environment Protection and Biodiversity Conservation Act (EPBC) (Ward-Paige et al. 2012). In 1999 this species was listed on Appendix II of the Convention on the Conservation of Migratory Species of Wild Animals (CMS) and on Appendix I in 2017 (CMS 2020).

The sand tiger shark (Carcharias taurus) in southern Australia has been protected from fishing since 1984, but due to the high rate of incidental hooking the population continues to decline (Ward-Paige et al. 2012).

Finning bans were thought to be a viable means to combat shark finning in the belief that they would result in a decline in shark mortality (Clarke et al. 2007, 2013). A fins-to-carcass ratio of $5 \%$ is usually adopted (calculated as fins being $5 \%$ of the weight of the sharks on board the fishing vessel), which supposedly indicates that no sharks have been finned and discarded at sea. However, these ratios are almost impossible to verify, especially when fins have been dried or are frozen. In addition, the legislation has not helped to improve data availability with respect to the true numbers and the species of sharks caught. Therefore, several jurisdictions, such as the European Union (EU), USA and Canada, as well as some RFMOs, have introduced a fins naturally attached (FNA) regulation that requires that fins cannot be cut off at sea but must be landed naturally attached to the body of the animal, which is the only guaranteed method to avoid shark finning (Cortés et al. 2006). Only then can the true numbers, species, and size of the sharks caught be reported accurately for the analysis of fishing-induced mortality. An FNA policy has been implemented in many countries and RFMOs including Costa Rica (2008), US (2011), EU (2013), Canada (2019), North East Atlantic Fisheries Commission (NEAFC) (2015), Northwest Atlantic Fisheries Organization (NAFO) (2017), and General Fisheries Commission for the Mediterranean (GFCM) (2018). The FNA policy has been an important improvement and is globally acknowledged as being the best practice (Cortés et al. 2006; Fischer et al. 2012, Biery et al. 2012).

However, there is no strict FNA policy for vast regions of the high seas, including the Indian Ocean (Indian Ocean Tuna Commission, (IOTC)), the Western Central Pacific (The Western and Central Pacific Fisheries Commission) (WCPFC)) the Atlantic Ocean and adjacent seas (The International Commission for the Conservation of Atlantic Tunas (ICCAT)) and the Eastern Pacific Ocean (Inter-American Tropical Tuna Commission (IATTC)). These authorities continue to allow the 5\% rule, or other fins-to-carcass ratios, as sufficient proof that finning does not occur. Therefore, for most regions globally, finning bans are still the only form of control on shark catches that have been implemented.

The Marine Stewardship Council (MSC), which awards its label to presumably sustainable fisheries, admits that finning still occurs in these certified fisheries. Its Fisheries Certification Standard still accepts the fins-to-carcass ratio with some degree of external validation as sufficient proof. It has therefore been criticized widely by environmental organizations and civil society for its lack of implementation of a FNA policy as this is the globally acknowledged best practice to demonstrate compliance and facilitates the enforcement of finning bans (Ziegler 2019).

For the industry, fins-to-carcass ratios are easy to implement compared with an FNA policy or catch reductions, and thus many fisheries still strongly oppose the adoption of an FNA policy. RFMOs have perceived the monitoring, assessment, and enforcement capacity required to manage shark fisheries as being prohibitively costly (Worm et al. 2013) but an FNA policy is globally considered to be much easier to monitor and control (Fischer et al. 2012). 
Nevertheless, finning bans and an FNA policy are difficult to enforce and their use appears to divert attention from the unsustainability of shark catches. The resulting trend has been towards less detaching of the fins but without a concomitant lessening of mortality (Clarke et al. 2013). A surplus of low-value shark meat has been forced onto markets around the world (Clarke et al. 2007; Dent \& Clarke 2015). Though only the fins are valuable, the rest of the shark has to be used. In Costa Rica and other South and Central American countries, for example, sharks were considered undesirable and not used for food prior to the 1980s. Then the inflated price of shark fins resulted in sharks of many species, from a wide variety of habitats, being targeted for their fins alone. The subsequent FNA policies obligated fishermen to land fins attached to the bodies, and the shark fin industry put the surplus meat on the market for domestic consumption. Merchants pushed the meat onto local consumers, relying on the use of various other names to sell it. Now Costa Ricans alone are consuming about 2000 tons of shark meat a year, and the situation is similar in many other countries (Porcher et al. 2019).

Another problem with the dumping of shark meat into local fish markets is that it is potentially poisonous. For example, the Florida Fish and Wildlife Conservation Commission's (FWC) (2020) fishing rules specify a minimum size of 54 inches for about half of the shark species caught. At the same time, the Florida Advisory on Fish Consumption (2019) advises that no species of coastal shark longer than 43 inches should ever be eaten by anyone due to its high mercury content. Thus fishermen are specifically advised to catch large sharks, which are the breeding females-mature female sharks of the species targeted are significantly larger than the males. Yet at the same time, they are considered too toxic to eat. The large species, such as hammerhead, lemon and tiger sharks that are targeted in Florida are apparently being killed simply for the value of their fins.

In parallel, the spiny dogfish fishery is being expanded in spite of the finding that $32 \%$ of spiny dogfish exceed the United States Environmental Protection Agency (US EPA) recommended threshold level of $0.3 \mathrm{ppm}$ of mercury (US EPA, 2000), and concerns that the meat could have an adverse effect on consumers (Taylor et al. 2014). The Maine Seafood Guide (2020) warns that dogfish meat "may contain amounts of mercury in excess of the recommendation of the USA Food and Drug Administration's (FDA) recommended limit". It advises that "pregnant and nursing women, women who may get pregnant, and children under 8 years of age" should not eat any shark, and others should eat no more than two such meals a month. Shark fins, especially the commonly traded species, are also found to contain high levels of toxins, including mercury and arsenic (Barcia et al. 2020). Shark fisheries are therefore targeting an animal that is a potential risk to human health and globally threatened.

\section{Markets}

Shark meat and oil are now being used in everything from make-up to dogfood, particularly from blue, shortfin mako (Isurus oxyrinchus) and scalloped hammerhead (Sphyrna lewini) sharks (Cardeñosa 2019). This indicates how widespread but hidden is the use of shark products once the animal has been killed for the fin trade.

Studies of the species supplying the markets in Hong Kong between 1999 and 2001 indicated that, at that time, elasmobranchs accessible to fisheries were facing four times the mortality that had been reported to the Food and Agriculture Organization of the United Nations (FAO) (Clarke et al. 2006a, b). This is the same trend that has been found in fisheries generally (Pauly \& Zeller 2016). Clarke et al. found that about 1.7 million tonnes of sharks a year were being sacrificed for the vanity soup and cautioned that these estimates were low and did not include shark mortality that did not produce fins (such as hooking mortality, post-release mortality, predatorial mortality during longlining, and the killing of sharks by fishermen to reduce bait loss on future sets, as well as incidental, artisanal and recreational catches and discards). In 2015, 52\% of fins (by weight) analysed in the Hong Kong market were CITESlisted sharks (Cardeñosa et al. 2019). In a later study, fins from 76 species of elasmobranchs were found being traded in Hong Kong, and one third of those species were considered to be threatened with extinction (Fields et al. 2017).

The high diversity of species in the Hong Kong shark fin market indicates the likelihood that species more sensitive to fishing pressure are being replaced by others as their numbers become depleted. Such substitution could mask losses of declining species (Fields et al. 2017).

When landings of species complexes appear to remain stable, or even increase in spite of intensive fishing, the declines or disappearance of the more sensitive members can go unnoticed while removal continues because overall yields are 
sustained by other, more productive species in an unperceived, yet effective, target replacement (Davidson et al. 2016). These factors impede the assessment of shark abundance and contribute to the uncertainties inherent in fisheries data (Ferretti et al. 2010). Increased pressure on such populations has often resulted in their total collapse (Stevens et al. 2000; Ferretti et al. 2010). Examples include the disappearance of three of the largest skate species from British waters, and steep declines in others, all while fishery reports on "skates and rays" claimed that the population was stable (Davidson et al. 2016).

The angel shark (Squatina squatina) was nearly fished to extinction in Europe. It was recorded and sold under the name "monkfish", but as the catch dwindled, fishermen substituted anglerfish (Lophius spp.) which was then sold under the same name (Davidson et al. 2016).

Similarly, as many popular fish species have become critically depleted and scarce, sharks have been substituted, using a false label to sell them. For example in 2019 Hobbs et al. used DNA Barcoding to identify species sold in "fish and chips" and other fish products sold in the UK. Out of 79 tested samples of fish and chips sold as takeaways, 71 were spiny dogfish—almost $90 \%$ of the tested samples. They were labelled as 'Rock Eel', 'Rock Salmon', 'Rock' or 'Huss', thereby making it almost impossible for consumers to know that they were eating shark meat, and possibly the meat of a threatened species - the spiny dogfish is critically endangered in the Eastern North Atlantic (Hobbs et al. 2019). Hobbs et al. (2109) also found that cheap fast food outlets seemed to be the best place to disguise shark meat and sell it under a false name.

\section{Ecology}

In pristine, unfished regions sharks are abundant and diverse (Ferretti et al. 2010). As top and middle predators, they were deeply woven into the aquatic temperate and tropical ecosystems of the planet through radial evolution into new ecological niches following several planet-wide extinctions (Kriwet \& Benton 2004; Kriwet et al. 2009; Guinot \& Calvin 2016).

The beginning of industrial fishing resulted in a large-scale ecological transformation, not only in terms of the size of individuals and the relative abundance of species, but also community biomass (Stevens et al. 2000; Ward \& Myers 2005; Myers et al. 2007; Ferretti et al. 2010; Travis et al. 2014). The removal of top predators causes alternating increases and declines in the abundance of lower levels on the food chain, an effect called a trophic cascade (Ward \& Myers 2005). However, due to the difficulties in studying marine ecosystems, particularly in deep waters, few such cases have been identified and little is known about the complex ecological roles played by sharks (Stevens et al., 2000; Mumby et al. 2006; Myers et al. 2007; Heithaus et al. 2008).

Along the Eastern coast of the USA, 11 species of large shark declined between 1970 and 2005, while catch rates for 14 small elasmobranch species increased from about $1 \%$ to some $26 \%$ per year (Myers et al. 2007; Heithaus et al. 2008). Ten-fold declines in 12 large pelagic predators between 1950 and 2000 were noted in the Pacific Ocean at the same time that pelagic stingrays (Dasyatis violacea) and other smaller elasmobranchs increased some 10- to 100-fold (Heithaus et al. 2008). In the North Sea, a rich ecosystem of elasmobranchs was changed to one consisting of a few small, productive species such as small spotted cat sharks (Scyliorhinus canicula) and small skates (Ferretti et al. 2010).

Food-web models suggest that large sharks are among the most strongly interacting species (Freire et al. 2008), and that their overfishing may have contributed to the degradation of the coral ecosystems in the Caribbean (Bascompte et al. 2005). A 'removal' computer simulation conducted for the reef ecosystem of Floreana Island in the Galápagos Islands found that sharks were at the top of the trophic scale and that their removal caused a four-level trophic cascade (Okey $e t$ al. 2004). Toothed cetaceans, sea lions, marine iguanas, and other mid-level predators were predicted to increase, which led directly to intensified predation on reef fish and a decline in their numbers. This in turn led to an increase in small benthic invertebrates. Other trophic cascades were also apparent. The removal of the sharks caused a rebalancing of the entire ecosystem.

The presence of large sharks has a marked effect on the behaviour of prey species. The removal of tiger sharks so affected the evasion behaviour of dugongs and green sea turtles in Shark Bay, Australia, that the sea floor patterns of sea grass and its nutrient composition were significantly changed (Heithaus et al. 2007, 2008). The removal of the great 
sharks is likely to have allowed smaller species to move into the sunlit upper layers of the ocean during the daylight hours, whereas formerly they only migrated upwards at night (Ward \& Myers 2005).

Some elasmobranchs, including reef and tiger sharks, leave their ranges for a period of weeks when fishing begins (Porcher 2010, 2017), putting their communities (Mourier et al. 2012, Papastamatiou et al. 2020) into disarray. This behaviour was independently seen in reef sharks in French Polynesia and tiger sharks in the Bahamas, suggesting that it is widespread.

Ecological communities respond strongly to the depletion of top predators and the resulting changes are widespread and long-lived (Heithaus et al. 2008; Ferretti et al. 2010). The extreme disruption wrought by more than seven decades of shark removal through trawling and longlining has caused major, cascading biodiversity shifts throughout the originally complex and diverse aquatic ecosystems that evolved over the past 500 million years, and these changes have been ignored by RFMOs (Travis et al. 2014).

\section{Shark Fishery Sustainability}

The global markets for shark meat and fins have been separate in the past, and relied on different species (Dent \& Clarke 2015). Only about $9 \%$ of elasmobranch fisheries are managed and considered sustainable (Simpfendorfer \& Dulvy 2017) and they are those few in the USA, New Zealand, Australia, and Canada that have fished sharks and skates for meat (Simpfendorfer \& Dulvy 2017). However, since these fisheries are now being propped up economically by the value of the sharks' fins (Shiffman \& Hueter 2017, Wiersma \& Carroll 2018) their long-term viability is questionable (Porcher et al. 2019).

In the USA, for example, the fishery for spiny dogfish is one of those considered sustainable (Simpfendorfer \& Dulvy 2017). It supplies more than $90 \%$ of the global trade in the species, the meat being sent to Europe while the fins go to Asia (Wiersma \& Carroll 2018). When decades of overfishing in the Northeast Atlantic caused a 95\% decline, and finally the closure, of the European spiny dogfish fishery, the USA expanded its take in the Northwest Atlantic in the 1990s to fill the demand (Wiersma \& Carroll 2018). More than 95\% of the sharks landed were mature females, the largest (and usually pregnant) dogfish (Rago et al. 1998). The biomass of the female spawning stock declined by $75 \%$ as a result (Wiersma \& Carroll 2018), and the fishery collapsed. However, the US Department of Commerce's National Oceanic and Atmospheric Administration (NOAA) declared the fishery rebuilt in 2010 (meaning that dogfish numbers had increased) and since then has been working to expand it, considering it underutilized (Witkin et al. 2015; NOAA 2016; St. Gelais \& Costa-Pierce 2016).

Spiny dogfish consume some of the same fishes that were depleted by fisheries on the eastern seaboard of the USA, and competed with cod for others. Thus, when the stocks of cod were depleted, dogfish had less competition, which supported an increase in their numbers. The expansion of the dogfish fishery was therefore driven in part by the hope of eradicating this competition for fishermen, with the claim that getting rid of spiny dogfish would help restore balance to the ecosystem (St. Gelais \& Costa-Pierce 2016). However, this increase was known to have resulted from the elimination of the large sharks (Heithaus et al. 2008), so the only way to restore the ecosystem is to permit their numbers to recover, not to eliminate the meso-predators and increase the damage and imbalance. Dogfish are fished in part by trawlers (NOAA 2020), which is highly destructive to the sea floor. Raising the level of this activity cannot be beneficial in any way.

In spite of the fact that dogfish meat is considered a danger to human health (Taylor et al. 2014; St. Gelais \& CostaPierce 2016), it has been marketed in the Atlantic states as a replacement for teleost fish whose stocks have been badlydepleted, including cod (Goldfarb 2016; New York Post 2016; Kowacki 2018). In 2018, commercial dogfish landings were estimated at 16.7 million pounds, while annual discards from commercial and recreational sources combined have remained at around 11 million pounds over the past decade. In 2014 recreational discards alone totalled 8 million pounds of shark (Atlantic States Marine Fisheries Commission 2018). Not only is the fishery itself destructive, but there is wastage on a similar scale.

Dulvy et al. (2008) found that the scale of threat to sharks is greater than that predicted by fisheries assessments and that local analyses may underestimate the risk of the collapse of global stocks. Though spiny dogfish numbers increased 
due to the removal of their predators and competitors, such increases can be quickly reversed if intensive fishing continues because of the high sensitivity of elasmobranchs to any changes in survival (Myers \& Worm 2003; Ferretti et al. 2010). The boom and bust pattern of the exploitation of this stock is typical of such targeted elasmobranch fisheries. Rapidly increasing yields are followed by sudden and extreme declines in catch, which signify not only the fragility of the fishery but also poor management (Cashion et al. 2019). USA Federal efforts to manage this stock have been relatively ineffective, hampered by high bycatch and the defiance of scientific advice by the Atlantic states. The stock is currently assessed as 'Endangered' by IUCN (with a declining population trend) on the basis of past and continuing declines, persistent market demand, targeted fishing, increasing discards, and growing pressure to reopen fisheries (Fordham et al. 2016). Nevertheless, US Atlantic spiny dogfish meat, fished mostly with gillnets and bottom longlines in the North West Atlantic, has been certified as sustainable since 2012 by MSC (MSC 2020).

\section{Fin Trade Sustainability}

Most species taken in the shark fin trade have never been known to support sustainably-managed fisheries (Fields et al. 2017). Simpfendorfer \& Dulvy (2017) claimed that fisheries serving the shark fin market could, with management, be made sustainable for two species: the shortfin mako and blue sharks in the North and South Atlantic, and the blue shark in the North Pacific.

In a parallel with many other species, and as a result of industrial fishing, the mean weight of the shortfin mako taken fell from $74 \mathrm{~kg}$ in the 1950s to just $38 \mathrm{~kg}$ in the 1990s (Ward \& Myers 2005), indicating how seriously the species has been affected by human predation. Like other cold water sharks, shortfin makos are slow growing and so are especially vulnerable to overfishing. They are killed for sport as well as for their meat and fins, are fished by many nations worldwide, and have suffered high mortality throughout their range (Ferretti et al. 2010; Rigby et al. 2019). The shortfin mako was assessed on the IUCN Red List in 2000 as being 'Lower risk/Near Threatened', and in 2009 it was reclassified as 'Vulnerable' (IUCN Red List). In 2017, the NOAA Fisheries website stated that it was being overfished in the North Atlantic (NOAA 2017), and in the 2019 IUCN Red List assessment it was re-classified as 'Endangered' worldwide, with a decreasing population trend. ICCAT's scientists therefore advised that there must be a ban on retention of the shortfin mako in the North Atlantic (ICCAT 2019), stating that the status of the species was so dire that even if all fishing was stopped immediately, their numbers would continue to decline for the next fifteen years, with a probability of only about 50\% that the stock would be rebuilt by 2045 (ICCAT 2019). The situation is considered to show a similar trend in the South Atlantic (ICCAT 2019).

But the implementation of a retention ban was blocked by both the USA and the European Union (EU) (ICCAT 2019), which chose to put short-term fishing interests before the need to protect this species. The EU fleets made $60 \%$ of the mako shark landings in the Atlantic in 2018 (ICCAT 2019) and the EU is responsible globally for more recorded shark catches than any other nation because of the large catches of Spain, Portugal and France, while the USA is the fifth most important shark hunting nation (TRAFFIC 2019). Yet the USA is claimed to be the best nation in the world in terms of shark conservation (Shiffman \& Hueter 2017).

The retention-ban motion for shortfin mako was not adopted and the continuing catch will not allow the stock to rebuild, even by 2070. Overfishing of this species continues (ICCAT 2019). Only Canada, which championed the retention ban together with Senegal in 2019, has so far prohibited the retention of mako, dead or alive, on its fleets since the beginning of the 2020/2021 fishing season (Fisheries and Oceans Canada 2020).

Shortfin mako have a greater landed value than blue sharks, and approximately two-thirds of them are retained after capture for use as meat. However, blue shark meat has no commercial value in North America. In both the USA and Canadian swordfish and tuna fisheries blue shark discards approach $100 \%$, and often exceed catches of the target species. Canada's North West Atlantic pelagic longline swordfish fishery, for example, reports catches of 20,000 swordfish and 100,000 blue sharks annually (Make Stewardship Count 2018), indicating the extreme wastage. In the North Atlantic 3 million blue sharks ( 100,000 t) have been estimated to be discarded each year (Campana 2016).

The blue shark is the source of more fins for the shark fin trade than any other species (Clarke et al. 2006b). Fields et al. (2017) estimated that 34 to $64 \%$ of shark fins traded in Hong Kong are from the blue shark, but the chairman of the Hong Kong Marine Products Association, Ricky Leung Lak-kee, stated that blue shark fins make up 60 to $80 \%$ of those 
consumed in Hong Kong (Kao 2017). The species also dominates the bycatch of longline fisheries (Oliver et al. 2015). Clarke et al. (2007) found that blue sharks were already being taken at levels possibly exceeding the maximum sustainable yield (MSY) between October 1999 and March 2001. Since then, catch rates in the North Pacific have been estimated to be declining at 5\% per year (Clarke et al. 2013), which suggests that the slaughter is unsustainable.

While the Northwest Atlantic Fisheries Organization (NAFO) and ICCAT are responsible for management of fisheries in the Northwest Atlantic, ICCAT is responsible for the longline fisheries that catch most of the pelagic shark species (Campana 2016). ICCAT represents 48 contracting nations and groups, including the EU, that between them fish more than 127 million hooks each year in the North Atlantic. Their priority is tunas, swordfish, and billfish; sharks are of lesser concern. Member nations provide data of highly variable quality for their fisheries and there are also several major fishing nations fishing the North Atlantic that provide no shark catch data to anyone, and are not party to ICCAT. As a result, ICCAT data for shortfin mako and blue sharks is so uncertain and incomplete as to suggest that these populations are anywhere from lightly-fished to overfished (Campana 2016).

Further, there is no effort to measure or compensate for discards, discard mortality, or hooking mortality. Until recently ICCAT applied different standards for sharks than for tunas, swordfish, and billfish, which Campana (2016) concluded meant that sharks were considered as a nuisance, not as a concern.

In 2018, 33,853 t of blue shark was reported as being taken in the North Atlantic, with Spain responsible for about $64 \%$ of this at 21,685 t (ICCAT 2019). At the same time, the FAO 2015 report lists Spain as the third most important shark fin producer in the world, and states that the country exported 3,409 $\mathrm{t}$ of shark fins to Southeast Asia each year between 2000 and 2011 (Dent \& Clarke 2015). However, the numbers of fins in Asian markets coming from the North Atlantic greatly exceeds the reported catch (Clarke 2008), indicating that there is substantial unreported finning which is not being taken into account by ICCAT. The lucrative shark fin market provides strong motivation. Sharks whose fins have been cut off, then were dumped, often still living, back into the sea, are not recorded because most western countries have banned the practice of shark finning. It is estimated that the actual numbers of blue sharks being killed are four times the number reported (Campana 2016).

In 2017, the blue shark was listed on Appendix II of the CMS listings (CMS 2020). In 2019 ICCAT found that there was such a high uncertainty in data inputs and model structural assumptions that the possibility of the stock being overfished, and overfishing occurring, could not be ruled out. It therefore established limits on blue shark takes in both the North and South Atlantic for the first time. In the North Atlantic the limit was set at 39,102 t (ICCAT 2019) somewhat higher than the 2018 catch, meaning that there is no requirement to reduce the catch. However, in 2020 EU approved a proposal from the 2019 ICCAT meeting for an active management of shark stocks in the future (EU Parliament 2020).

Most sharks caught in the Atlantic are juveniles (ICCAT 2019), a strong sign of over-exploitation. Killed before reproducing, their numbers will not be sustained. Similarly, in Peru, of 11,166 blue and mako sharks caught in a longline fishery, $83.7 \%$ were sexually immature and under the legal minimum landing size (Doherty et al. 2014). With $90 \%$ of teleost stocks overfished (World Bank 2017), blue sharks are increasingly caught globally for their previously low-valued meat. In the ICCAT area alone, reported landings of blue shark have increased by a factor of about six from 11,300 metric tonnes (t) in 1994 to 70,200 t in 2016, and 68,200 t in 2018 (ICCAT 2019). Landings by European fleets in the Atlantic have rocketed, within a period of only twelve years, from a combined catch of less than $5000 \mathrm{mt}$ in 2004 to about 53,000 $\mathrm{t}$ in 2016, thereby accounting for almost $75 \%$ of all landings in the South and North Atlantic in 2016 (ICCAT 2019). In Chile retention of blue sharks increased almost sixty-fold between 1999 and 2009 (Davidson et al. 2016).

Simpfendorfer \& Dulvy (2017) based their prediction of sustainability for the blue shark on MSY. They defined sustainability as the "current biomass being greater than that required to achieve MSY or current fishing mortality being less than that which will yield MSY". But MSY is estimated from actual landings, so is hardly applicable to a largely discarded species (Campana 2016). Further, this method is no longer considered to be applicable to fisheries that are overfished and require stock rebuilding: spawning biomass first has to be restored, then the mortality from fishing must always be lower than the mortality to maintain MSY (Hilborn \& Walters 1992; Tsikliras \& Froese 2019).

Just three years after Simpfendorfer \& Dulvy (2017) predicted sustainable shortfin mako and blue shark fisheries for the shark fin trade, the unfolding trends indicate that they were wrong. 


\section{High Seas Fishing Economics}

The fishing industry is currently propped up by an estimated US\$35.4 billion in subsidies (Sumaila et al. 2019). China provides the highest subsidy among nations, at $21 \%$ of the total, followed by the USA at $10 \%$ and the Republic of Korea at 9\%. These subsidies far exceed the profits from their fishing (Sala et al. 2018). The only fishing fleets that are currently profitable are the longliners and purse-seiners which target the highest-valued marine animals: tuna and sharks (Sala et al. 2018). Fully 54\% are unprofitable, especially the largest fishing fleets. The current scale is enabled only by those large government subsidies (Sala et al. 2018; Sumaila et al. 2019). For example, the diesel for the long distance fishing fleets of the EU is paid for by subsidies, which allow them to go fishing in the distant Indian Ocean and in the Western and Central Pacific. There, with their larger vessels and superior technology, they compete with the local fisheries for the remaining stocks of fish (Sala et al. 2018, Sumaila et al. 2019). Deep-sea trawling, which is one of the most destructive fishing practices, is especially supported by subsidies, and even then, $32 \%$ of deep-sea trawling is unprofitable (Sumaila et al. 2010, 2019; Norse et al. 2011; Sala et al. 2018).

Evidently, high seas fishing activity would be completely transformed if subsidies were halted. For example, in the case of Spain, a top provider of blue shark fins to Asia, its most profitable fisheries are longliners in the Western Indian Ocean, the Southeast Pacific, and the Southwest Pacific, far from its own EEZs. But many of its distant purse-seine fisheries would not be profitable without subsidies, and its high seas bottom trawling is unprofitable everywhere without subsidies (Sala et al. 2018).

A global study by the World Bank, Sunken Billions Revisited (2017), reported that overfishing has resulted in a loss of about US $\$ 83$ billion yearly. It found that fishing effort must be reduced to get the best economic result for solving the evolving global fisheries crisis. The fundamental reforms that are required must follow two parallel and simultaneous paths: (a) stock recovery, which would require giving depleted and over-exploited stocks a chance to recover, primarily by reducing fishing effort, and (b) restoring the integrity of the habitats on which the stocks depend (including mangroves, coral reefs, and seagrass beds). This is therefore the course of action which should be taken. However, because the shark fin trade has made the top and middle predators valuable, global fisheries are targeting them instead, despite their high ecological importance and the toxicity of their fins and meat. They are increasingly threatened.

Clearly, shutting down a large proportion of the world's industrial fishing fleet will be disruptive and social unrest is predicted because millions of fishers will have to switch to other occupations. It has been recommended that the fishing subsidies that have encouraged overfishing in the past be used to help ease the social transition (World Bank 2017; IPBES 2019 ).

\section{Discussion}

We have known for decades that sharks are vulnerable to overfishing (e.g. Travis 1961; Walker 1998; Castro et al. 1999), that they are under high fishing pressure (Myers \& Worm 2003; Worm et al. 2013), are of high ecological value (Stevens et al. 2000; Ferretti et al. 2010) and that those accessible to commercial fishing fleets are threatened with global extinction (Dulvy et al. 2014). One scientist after another has advised over many years that species-specific records are a necessary prelude to the possibility of sustainable management of sharks, and that collecting data, especially in data-poor regions, should be a priority (Stevens et al. 2000; Ward-Paige et al. 2012; Oliver et al. 2015; Pauly \& Zeller 2015). Industrial fishing fleets operate over vast regions and usually in international waters (Kroodsma et al. 2018). International cooperation in the collection and availability of accurate data is therefore necessary on a global scale, to monitor and manage elasmobranch catch and bycatch at the species-specific level (Oliver et al. 2015; Davidson et al. 2016). Yet it was found in 2015 that of the top ten shark fishing nations, only the USA had kept reasonable records, and only half had kept any records at all (Oliver et al. 2015). Lam \& Sadovy de Mitcheson affirmed in 2011 that at that time, Chinese shark catch data were classified as state secrets and such data continue to be unavailable publicly. So although China fishes more intensively than any other nation (Sala et al. 2018) its large shark catches have not been included in any fisheries' assessments. 
Twenty years ago an international plan of action was drafted to address illegal, unreported, and unregulated fishing (Doulman 2000). It was considered vital to gain control of illegal, unreported, and unregulated fishing to establish sustainability in shark fisheries. However, illegal fishing continues unabated and shark fishing pressure has continued to increase (Ferretti et al. 2010), even though - or because - official landings have been declining since 2003 due to overfishing (Davidson et al. 2016).

The shortfin mako shark went from 'Lower Risk' to 'Endangered' in less than 20 years with no conservation action, indicating that RFMOs did not maintain shark populations at healthy levels. The subsequent refusal of the USA and the EU to follow ICCAT's science-based recommendations (ICCAT 2019) illustrates how industry interests take precedence over the conservation of valuable, high-priced animals, even in such a state of crisis as is apparent for the shortfin mako stocks of the Atlantic. This tendency is seen throughout the history of shark fishing (Ward \& Myers 2005; Campana 2016; Fordham et al. 2016). RFMO priority is to maximize the profits of their fisheries, and managing sharks can reduce those profits (Campana 2016). Even where possible, with few exceptions, RFMOs have not intervened as sharks have been increasingly overfished (Dulvy et al. 2014).

The cultural idea that catches should be maximized for every possible species is by no means universal, even in maritime nations. French Polynesia, for example, wanted its sharks neither fished nor disturbed, and when companies from Asia began intensive shark removal throughout the vast archipelago of that island nation, the government responded by turning its entire EEZ, which is the size of Europe, into a shark sanctuary (Porcher 2010; Ward-Paige 2017). Other nations too, have become shark sanctuaries in response to the nature of the shark fin trade (Ward-Paige 2017; Animal Welfare Institute 2019).

However, in the USA, which boasts the biggest recreational shark fishery in the world (Walker 1998), fishermen are applying powerful political pressure to be allowed to continue to fish sharks and profit from the shark fin trade, in spite of the global danger to sharks, even attempting to scare Americans with the threat of more shark attacks if they cannot kill the animals (Gehan 2019). When Texas passed a law that required that all dead sharks shipped through the state must have their fins naturally attached, meaning that fishermen could no longer sell the fins, the Western Gulf of Mexico shark fishery was effectively shut down in 2019 (Gehan 2019), a telling illustration of how the shark fin market drives shark fisheries.

The detailed recording and international cooperation that would be necessary to make commercial shark fishing sustainable in the face of the shark fin trade would seem to be prohibitively difficult. Fisheries management schemes are expensive to set up and operate. Expenses range from those for scientific advice and management, to enforcement, including monitoring, control, and surveillance, and they can reach 14\% of the value of landings (World Bank 2017). However, most of the cost is borne by the public sector, while the benefits are concentrated on the fishers (World Bank 2017; Ferretti et al. 2020). Neither the necessary funds, nor an international organization that could create such a cooperative network exist. It would require that every country keep politics, financial self-interest, corruption, and criminality out of the process.

Further, the extent of surveillance and monitoring that would be required, as well as its cost, is prohibitive. Even $100 \%$ human observer coverage on all vessels would be insufficient to ensure that finning or illegal retainment does not take place (Human Rights at Sea 2020; McVeigh \& Firdaus 2020; Greenpeace 2020). Due to the illegal character of the shark fin trade and the huge profits associated with it, observers have been murdered.

Severe human rights abuses also happen on a regular basis, especially on the long distance fleets of WCPFC, including on MSC certified fisheries vessels, as revealed by Greenpeace (2020) and Human Rights at Sea (2020). It is apparent from the shark fin industry that illegal, unreported, and unregulated activities tend to accompany the abuse of, and crimes against, humans (IPBES 2019). As a further example, two of us have been threatened. In Hong Kong, BWD was threatened with violence at a public meeting. In French Polynesia, IFP was threatened during her ethological study of reef sharks. When the local fishermen began finning sharks, they circulated many negative stories about them, including the idea that the animals would be coming out on the beaches to eat babies if they did not kill them. Due to their attitude, IFP had to be extremely secretive on each visit to her study area. Following a television appearance in which she spoke of the need to protect the remaining sharks due to the extreme losses that had occurred, there was an outbreak of extreme hostility against her, including a death threat. There were also attacks on tourists who were 
concerned about the shark finning openly taking place. The shark fin trade had a very bad effect on the population; the Polynesian culture is traditionally non-violent.

In Asian consumer nations, there is little government interest in regulating the shark fin market and the resources required to do so are simply not in place (Sadovy de Mitcheson et al. 2018). Shark fin consumers can afford to pay high prices for them and are quite unconcerned about sustainability. The involvement of fisheries worldwide and the participation of criminal networks in a trade driven by high prices and rich customers, contrasted with the catastrophic depletion of the animals supplying the fins (Fields et al. 2017), makes the shark fin trade unsustainable.

Even light fishing pressure by artisanal and subsistence fishing in remote regions, or shark netting programs to 'protect' beaches, can cause serious depletion of large coastal sharks (Ferretti et al. 2010). Since the stocks of most elasmobranchs have collapsed, and in view of their low productivity, truly sustainable shark fishing would therefore now require the enforcement of near-zero shark mortality globally to allow both top predators and their small elasmobranch prey to recover (Ward-Paige et al. 2012; Davidson et al. 2016). Clearly this would not support even a tiny fraction of the shark fin trade.

The tendency to turn to fishing sharks because the shark fin trade has made them profitable, instead of concentrating on the recovery of the gravely depleted teleost fish stocks and their habitats (with the goal of long-term yields from healthy fish stocks in the future), is a dangerous course which should not be pursued. Sharks are less productive than teleosts but as top and middle predators they are of high ecological importance. They will go the way of the teleost fish, and much more quickly, if the current trend continues. No lessons have been learned from the demise of Grand Banks cod (Mason 2002) and North Sea herring (Dickey-Collas 2010) it seems.

Given the market interplay of supply and demand, wherein the desire for money fuels the targeted hunt for sharks and rich customers supply it, the way to stop the slaughter is to stop the shark fin trade itself. Stopping demand and disrupting international supply chains are key aspects of this.

It has been 'scientifically' argued that fishermen should treat fish as they wish because they are predators and part of the food chain (Diggles et al. 2011). In contrast, our civilization prides itself on the idea that humanity uses reason in its decision-making, rather than following its instincts. But Diggles has reminded us of the true situation: the worlds' fishermen are in the same position as any other predator that is in the process of eliminating its prey. With the human population as over-grown as it is, it has been known for decades that the moment would come in which no wild prey would be able to sustain us. We have the capacity to recognize the difference between instinctual drive and reasoned thought, yet reason (i.e. science) is often rejected in negotiations. Territorial interests supervene and limit international cooperation (Lorenz 1963), and this carries over into the management of globally-important species. Such barriers must be overcome, otherwise the current pattern of species depletion, extinction, and the unravelling of the planet's ecosystems will continue and accelerate, eventually to the severe detriment of humanity (Barry 2014; IPBES 2019).

There has been an ethical failure in fisheries, illustrated by the industry's willingness to pillage without regard for the health of the biosphere (Travis et al. 2014), the level of bycatch that has been treated as tolerable (Harrington et al. 2005; Ferretti et al. 2010; Oliver et al. 2015), and the willingness to put short-term financial interests first (Fordham et al. 2016; St. Gelais \& Costa-Pierce 2016; Shiffman \& Hueter 2017). Deep-sea trawlers mine ecosystems in the knowledge that they will not recover (Sumaila et al. 2010; Norse et al. 2011). Though the danger to marine life posed by abandoned fishing nets has long been recognized, for more than three decades the fishing industry has trailed nets to significant depths below dFADs, killing large numbers of sea turtles and sharks, and this mortality from entanglement has been ignored by fisheries scientists and RFMOs alike (Filmalter et al. 2013). More than 50\% of all floating objects are dFADs, many of which were abandoned by the fleet that launched them. They are able to drift for as long as two years, can cover distances of more than 10,000 km (Hanich et al. 2019), and badly damage the shore when they beach (Balderson \& Martin 2015).

Yet fish from such fisheries have been certified as "sustainable" by MSC, which claims to use a high standard in recommending only sustainable seafood to a trusting public. However in practice, it is applying much lower industry standards for certification (MSC 2020b; Kearns 2015; Edwards 2018), as repeated criticism by scientists and NGOs (Make Stewardship Count 2018) also suggests. MSC has even granted sustainable fishing certifications to fisheries in spite of proof that shark finning was occurring. Conformity Assessment Bodies (CABs), which perform the assessment and certification of fisheries, are advised by MSC to consider only systematic finning or successful convictions as 
evidence for non-compliance with MSC's proclaimed zero-tolerance policy on finning (Arauz 2018; Ziegler 2019). Neither has ever deemed a fishery non-eligible for certification.

This domination by industry must end if the planet's aquatic ecosystems are to be saved from ecological collapse (IPBES 2019).

\section{Conclusions}

Fishing effort must be diminished by a large proportion to permit the damaged ecosystems of oceans, coral reefs and lagoons, mangroves, estuaries, rivers, lakes, and coastlines to recover. Fishing subsidies must end. The money should be used instead to help fishermen switch to other occupations, including, for example, ecotourism, and to police the shores and reefs they once fished. Severe sanctions, including heavy fines and vessel seizures, should be levied on violators, and those revenues invested in policing and education.

Educating fishers to protect their damaged sea coast is an option that has been found to be highly successful (Alcala 1998). The installation and protection of marine protected areas (MPAs) also helps to increase the abundance of fish in adjacent areas, which will ultimately help to secure income for them.

A radical change is needed to ensure that fishers can sell their catch at a good price and make a living without overfishing and without damaging the environment. Fishing methods must be transformed in such a way that bycatch is completely avoided. The inevitable reduction in fishing efficiency and the increased costs thereby incurred will mean that consumers will have to pay higher prices to eat fish. But fish provide a high quality protein, and a higher price would reflect more truly the value of such wild prey.

Critically, international cooperation is needed to protect sharks from the shark fin trade. For pelagic species of sharks, large MPAs and no-take zones including the High Seas are required for effective protection, as most are highly migratory. Therefore Queiroz et al. (2019), concluded that there is an urgent need for conservation and management measures at high-seas hotspots of shark space. At least $30 \%$ of the ocean should be set aside as MPAs to recover (O'Leary et al. 2016). Designation of such MPAs should take the high degree of spatial overlap between sharks and industrial fishing vessels into consideration, especially in those areas that attract fish because of their favourable productivity and temperature profiles (Baum 2019).

Protection of all sharks, manta rays, devil rays and rhino rays through an Appendix I CITES listing should be effected immediately; the shark fin trade takes all fins, therefore all should be listed. The claim that there is insufficient data to justify listings on Appendix I does not hold up when it is impossible to assess the status of sharks accurately. The evidence of over-depletion revealed by a study of the literature provides an alarming warning regarding what is occurring and lays out sufficient reason to do so. The illegal character and the high economic incentives associated with the shark fin trade heighten its danger for the increasingly depleted animals supplying it. The increasing takes of shark liver oil from threatened species, with at-sea processing, is of the same character (Sea Shepherd 2017a, b). The ineffectiveness of Appendix II listings indicates that the level of protection afforded to all accessible sharks must be significantly improved or the current trend towards extinction will continue to its obvious conclusion in the next few decades. There is already a precedent in listing look-alike species (Vincent et al. 2013), and the plight of sharks warrants such a measure.

Such a step would also benefit local communities who depend on the sea for their protein. In artisanal fisheries, the elasmobranch catch is generally fully-utilized (Oliver et al. 2015) and with no shark exports, the market would remain local, and prices would not be jacked-up to export levels.

A CITES I listing for sharks would greatly simplify management and policing by eliminating the need to identify illegally-caught species, or parts thereof, at border crossings, as well as the continuous demands for more speciesspecific information in the various regions as required by "Non-detrimental" findings. Such species data is expensive, difficult, and sometimes impossible to get, while its absence delays action under current rules, and the trade continues.

Shark bycatch taken by longliners and trawlers should be reduced using available methods (Kaplan et al. 2007; Erickson \& Berkeley 2008; Oliver et al. 2015) and measures should be taken to reduce shark bycatch and mortality for 
all fishing gear, by implementing 'best handling' practices for the release of all species in all gear types, so that the highest possible proportion will survive mandatory release. A global shift towards more selective fishing methods, away from today's highly efficient, but also very unselective and destructive fishing methods, should also be an objective if we want the biodiversity in our oceans to survive beyond this century (Reid et al. 2016; Zhou et al. 2019).

More scientific observers should be deployed by RFMOs (Campana 2016, Baum 2019). However, given the increasing numbers of human rights violations, disappearances, and even murder of observers, they should not be used for enforcement of regulations nor compliance monitoring. To effect this there are now remote electronic monitoring tools available which are tamper-proof and can cover all activities on board. Monitoring of landings and trans-shipment activities needs to be mandatory, as well as positioning data via Automatic Identification System (AIS) for all fishing vessels. Such equipment should be installed in such a way that it cannot be switched off (Sumaila et al. 2020). Implementation of a comprehensive monitoring and surveillance system combining both human observers and remote electronic monitoring should be a priority task for all RFMOs (Ewell et al. 2020).

Change can also come through cultural shifts. Such a change with respect to shark fin soup is already ongoing in China (Sadovy de Mitcheson et al. 2018). It needs to be strengthened there and in other shark fin consumer countries. Although demand is decreasing in China and Hong Kong, it is growing in Thailand, Japan, and Malaysia (Dent \& Clarke 2015). Removing shark fin from menus and retail markets in consumer countries is of top priority (Sadovy de Mitcheson et al. 2018) and shark fin trade bans should be adopted as widely as possible. A trade ban is easier to enforce than fishing regulations on the high seas while taking away the enormous profit, and thereby the incentive, to catch sharks. In the USA, the Shark Fin Trade Elimination Act has passed through Congress, and at this writing is awaiting passage in the Senate. Fourteen states have banned shark fins, and Florida has also passed an import ban on fins in 2020. There is a trade ban in Canada, requiring all shark fins to remain naturally attached to the body of the animal for import and export, and political pressure is being applied to effect a trade ban in Europe.

That one soup recipe, in just one of the world's many cultures, could have had such a serious effect on the status of as many species as are represented by the class of Chondrichthyes, is a telling indictment of the priorities of humanity. Participation in such a market is an ethical question, not just a commercial one. The way the industrialized western nations have joined the hunt for sharks to profit from such a market highlights the need to address this facet of the problem. There must be a shift in attitude towards the management of the biosphere in the interests of sustainability, not of sharks alone, although they may be taken as key indicators, but to permit our civilization to continue on in good health.

If history has taught us anything, no wild animal can withstand targeted industrial-scale hunting long term-not whales, not sea turtles, not fish, and certainly not sharks.

\section{References}

Alcala AC (1998) Community-based coastal resource management in the Philippines: a case study. Coastal and Ocean Management 38:179-186.

Amorim AF, Arfelli CA, Fagundes L (1998) Pelagic elasmobranchs caught by longliners off Southern Brazil during 1974-97: an overview. Mar. Freshw. Res. 49, 621- 632.

Animal Welfare Institute (2019) International Shark Finning Bans and Policies <awionline.org/content/internationalshark-finning-bans-and-policies> Accessed 14 August 2020

Arauz R (2018) NGOs adverse MSC Sustainable Fisheries Certification granted to Western and Central Pacific Tuna Fishery. www.make-stewardship-count.org/ngos-adverse-msc-sustainable-fisheries-certification-granted-to-westernand-central-pacific-tuna-fishery

Atlantic States Marine Fisheries Commission (2018) Spiny Dogfish. www.asmfc.org/species/spiny-dogfish Accessed 17 April 2020 
Balderson SD, Martin LEC (2015) Environmental impacts and causation of 'beached' Drifting Fish Aggregating Devices around Seychelles Islands: a preliminary report on data collected by Island Conservation Society. IOTC-2015WPEB11-39

Baum J, (2019) Industrial fishing boats leave few safe havens for sharks on the high seas. Nature 572, 449-450 doi: 10.1038/d41586-019-02357-2Barcia LG, Argiro J, Babcock EA, Cai Y, Shea SKH, Chapman DD (2020) Mercury and arsenic in processed fins from nine of the most traded shark species in the Hong Kong and China dried seafood markets: The potential health risks of shark fin soup. Marine Pollution Bulletin, 157: 111281. doi.org/10.1016/j.marpolbul.2020.111281

Barry G (2014) Terrestrial ecosystem loss and biosphere collapse. Management of Environmental Quality. 25(5):542563. doi.org/10.1108/MEQ-06-2013-0069

Bascomte J, Melián CJ, Sala E (2005) Interaction strength combinations and the overfishing of a marine food web. Proceedings of the National Academy of Sciences of the United States of America. 102(15):5443-5447. doi.org/10.1073/pnas.0501562102

Biery, L. and Pauly, D. (2012) A global review of species specific shark fin to body mass ratios and relevant legislation Journal of Fish Biology 80 (5): 1643-1677 https://onlinelibrary.wiley.com/doi/abs/10.1111/j.1095- 8649.2011.03215.x

Booth H, Pooley S, Clements T, Putra, MIH, Lestari WP, Lewis S, Warwick L, Milner-Gulland EJ (2020) Assessing the impact of regulations on the use and trade of wildlife: An operational framework, with a case study on manta rays. Global Ecology and Conservation. 22: e00953. doi.org/10.1016/j.gecco.2020.e00953.

Campana SE (2016) Transboundary movements, unmonitored fishing mortality, and ineffective international fisheries management pose risks for pelagic sharks in the Northwest Atlantic. Can. J. Fish. Aquat. Sci. 73:1599-1607.

Cardeñosa D, Fields AT, Babcock EA, Zhang H, Feldheim K, Shea SKH, Fischer GA, Chapman DD (2018) CITESlisted sharks remain among the top species in the contemporary fin trade. Conservation Letters. 11:e12457 doi.org/10.1111/conl.12457

Cardeñosa D (2019) Genetic identification of threatened shark species in pet food and beauty care products. Conserv Genet 20:1383-1387. 20, 1383-1387 doi.org/10.1007/s10592-019-01221-0

Cashion MS, Bailly N, Pauly D (2019) Official catch data under-represent shark and ray taxa caught in Mediterranean and Black Sea fisheries. Marine Policy. 105:1-9. doi.org/10.1016/j.marpol.2019.02.041.

Castro JI, Woodley CM, Brudek RL (1999) A Preliminary Evaluation of Status of Shark Species. FAO Fisheries Technical Paper 380. Food and Agriculture Organization, Rome.

Chabrol R, Nouvian C (2012) The hideous price of beauty. An investigation into the market of deep-sea shark liver oil. Bloom Association www.bloomassociation.org/en/wp-content/uploads/2013/10/ENG_Squalene_4-pager.pdf

Clarke S, Magnussen JE, Abercrombie DL, McAllister M, Shivji M (2006) Identification of shark species composition and proportion in the Hong Kong shark fin market based on molecular genetics and trade records. Conserv. Biol. 20:201-211.

Clarke S, Murdoch K, McAllister M, Milner-Gulland EJ, Kirkwood GP, Michielsens C, Agnew DJ, Pikitch EK, Nakano H, and Shivji MS. (2006) Global estimates of shark catches using trade records from commercial markets. Ecology Letters. 9 (10): 1115-1126 doi.org//10.1111/j.1461-0248.2006.00968.x.

Clarke S, Milner-Gulland EJ, Bjørndal T (2007) Social, economic and regulatory drivers of the shark fin trade. Marine Resource Economics 22:305-327.

Clarke S (2008) Use of shark fin trade data to estimate historic total shark removals in the Atlantic Ocean. Aquat. Living Resour. 21: 373-381 doi.org/10.1051/alr:2008060

Clarke SC, Harley SJ, Hoyle SD, Rice JS (2013) Population trends in Pacific Oceanic sharks and the utility of regulations on shark finning. Conserv Biol 00: 1-13. doi.org/10.1111/j.1523-1739.2012.01943.x 
Convention on the Conservation of Migratory Species of Wild Animals https://www.cms.int/en/species?field_species_class_tid=1857 Accessed 19 August 2020

Cortés E, Neer JA, (2006) Preliminary reassessment of the validity of the 5\% fin to carcass weight ratio for sharks. Collect. Vol. Sci. Pap. ICCAT 59(3): 1025-1036.

CREMA (2018) Costa Rica, Don‘t Export that Pile of Hammerhead Shark Fins. www.cremacr.org/en/policyadvocacy/campaigns/costa-rica-dont-export-that-stockpile-of-hammerhead-shark-fins/

Davidson LNK, Krawchuk MA, Dulvy NK (2016) Why have global shark and ray landings declined: improved management or overfishing? Fish and Fisheries. 17:438-458 doi.org/10.1111/faf.12119

Dent F, Clarke SC (2015) State of the Global Market for Shark Products. United Nations Food and Agriculture Organization Fisheries and Aquaculture. (Technical Paper 590)

Dickey-Collas M, Nash RDM, Brunel T, van Damme CJG, Marshall TC, Payne MR, Corten A, Geffen AJ, Peck MA, Hatfield EMC, Hintzen NT, Enberg K, Kell LT, Simmonds JE (2010) Lessons learned from stock collapse and recovery of North Sea herring: a review. ICES Journal of Marine Science, 67(9):1875-1886 doi.org/10.1093/icesjms/fsq033

Diggles BK, Cooke SJ, Rose JD, Sawynok W (2011) Ecology and welfare of aquatic animals in wild capture fisheries. Rev Fish Biol Fish 21:739-765.

Doherty PD, Alfaro-Shigueto J, Hodgson DJ, Mangel JC, Witt MJ, Godley BJ (2014) Big catch, little sharks: Insight into Peruvian small-scale longline fisheries. 4(12): 2375 - 2383 Ecology and Evolution doi.org/ 10.1002/ece3.1104.

Doulman DJ (2000) Illegal, Unreported and Unregulated Fishing: Mandate for an International Plan of Action. Document AUS:IUU/2000/4. Rome, Italy. www.fao.org/docrep/005/Y3274E/y3274e06.htm Accessed 17 April, 2020

Dulvy NK, Baum JK, Clarke S, Compagno LJV, Cortés E, Domingo A, Fordham S, Fowler S, Francis MP, Gibson C, Martínez J, Musick, JA, Soldo A, Stevens, J.D, Valenti S. (2008) You can swim but you can't hide: the global status and conservation of oceanic pelagic sharks and rays. Aquat. Conserv. Mar. Freshw. Ecosyst. 18:459-482.

doi.org/10.1002/aqc.975

Dulvy NK, Fowler SL, Musick JA, Cavanagh RD, Kyne PM, Harrison LR, Carlson JK, Davidson LN, Fordham SV, Francis MP, Pollock CM, Simpfendorfer CA, Burgess GH, Carpenter KE, Compagno LJ, Ebert DA, Gibson C, Heupel MR, Livingstone SR, Sanciangco JC, Stevens JD, Valenti S, White WT (2014) Extinction risk and conservation of the world's sharks and rays. eLife 3: e00590

Edwards S (2018) WWF statement on MSC certification of Spanish Purse Seine "Echebastar" Fishery in the Indian Ocean. wwf.panda.org/wwf_news/press_releases/?337217/WWF-Statement-on-MSC-certification-of-Spanish-PurseSeine-Echebastar-Fishery-in-the-Indian-Ocean\%C2\%A0

Environmental Protection Agency, USA (US EPA) (2000) Guidance for Assessing Chemical Contaminant Data for Use in Fish Advisories, Volume 2: Risk Assessment and Fish Consumption Limits. 3rd ed. U.S. Environmental Protection Agency, Office of Science and Technology, Office of Water, Washington, D.C. EPA-823-B-00-008.

www.epa.gov/waterscience/fish/advice/volume2/index.html Accessed 14 April 2020

Erickson DL, Berkeley SA (2008) Methods to reduce bycatch mortality in longline fisheries. In Sharks of the open ocean: biology, fisheries and conservation. Edited by Camhi MD, Pikitch EK, Babcock EA. Blackwell Publishing, Oxford, UK pp. 462-471.

European Union Plenary sitting (2020) Recommendation on the draft Council decision on the conclusion, on behalf of the European Union, of the Protocol to amend the International Convention for the Conservation of Atlantic Tunas (13447/2019 - C9-0187/2019 - 2019/0225(NLE)) 27.4.2020

www.europarl.europa.eu/doceo/document/A-9-2020-0089_EN.pdf Accessed 07 August 2020

Ewell C, Hocevar J, Mitchell E, Snowden S, Jacquet J. (2020) An evaluation of Regional Fisheries Management Organization at-sea compliance monitoring and observer programs Marine Policy 115:103842 doi.org/ 10.1016/j.marpol.2020.103842 
Ferretti F, Myers RA, Serena F, Lotze HK (2008) Loss of large predatory sharks from the Mediterranean Sea. Conserv. Biol. 22, 952-964.

Ferretti F, Worm B, Britten GL, Heithaus MR, Lotze HK (2010) Patterns and ecosystem consequences of shark declines in the ocean. Ecology Letters. 13(8):1055-1071 doi.org/0.1111/j.1461-0248.2010.01489.x

Ferretti F, Jacoby DMP, Pfleger MO, White TD, Dent F, Micheli F, Rosenberg AA, Crowder, LB, Block, BA (2020) Shark fin trade bans and sustainable shark fisheries. Conservation Letters. e12708. doi.org/10.1111/conl.12708

Fields AT, Fischer GA, Shea, SKH, Zhang H, Abercrombie DL, Feldheim KA, Babcock EA, Chapman DD, (2017) Species composition of the international shark fin trade assessed through a retail-market survey in Hong Kong, Conserv. Biol. 1523-1739

Filmalter JD, Capello M, Deneubourg J, Cowley PD, Dagorn L (2013) Looking behind the curtain: quantifying massive shark mortality in fish aggregating devices. Frontiers in Ecology and the Environment 11: 291-296. doi.org/10.1890/130045

Fischer J, Erikstein K, D'Offay B, Guggisberg S, Barone M. (2012) Review of the Implementation of the International Plan of Action for the Conservation and Management of Sharks FAO Fisheries and Aquaculture Circular. No. 1076 2012, p65 www.fao.org/3/i3036e/i3036e00.htm Accessed 12 August 2020

Fisheries and Oceans Canada (2020) North Atlantic Shortfin Mako Management 2020-2021 ecologyaction.ca/sites/default/files/images-documents/shortfin\%20mako.pdf Accessed 12 August 2020

Florida Department of Health (2019) Florida Advisory on Fish Consumption. www.floridahealth.gov/programs-andservices/prevention/healthy-weight/nutrition/seafood-consumption/_documents/fish-advisory-big-book2019.pdf Accessed 17 April 2020

Florida Fish and Wildlife Conservation Commission. myfwc.com/fishing/saltwater/recreational/sharks/ Accessed 14 April 2020

Fordham S, Fowler SL, Coelho RP, Goldman K, Francis MP (2016) The IUCN Red List of Threatened Species: Squalus acanthias. doi.org/10.2305/IUCN.UK.2016-1.RLTS.T91209505A2898271.en Accessed 14 April 2020

Freire KD, Christensen V, Pauly D (2008) Description of the East Brazil Large Marine Ecosystem using a trophic model. Biology. Corpus ID: 3911634 doi.org/10.3989/scimar.2008.72n3477

Friedlander A, Beets J, Tobias W (1994) Effects of Fish Aggregating Device Design and Location on Fishing Success in the U.S. Virgin Islands. Bulletin of Marine Science. 55(2-3):592-601

Froese R, Zeller D, Kleisner K, Pauly D (2012) What catch data can tell us about the status of global fisheries. Mar Biol 159:1283-1292 doi.org/10.1007/s00227-012-1909-6

Gehan, SM (2019) Testimony of the Sustainable Shark Alliance Before the House Subcommittee on Water, Oceans, and Wildlife March 26, 2019

naturalresources.house.gov/imo/media/doc/Gehan\%20Testimony\%20WOW\%20Leg\%20Hrg\%2003.26.19.pdf

Accessed 14 April 2020

Goldfarb B, (2016) Cod Is Dead-Is Dogfish the Answer? Boston Newsmagazine. www.bostonmagazine.com/restaurants/2016/08/14/dogfish Accessed 17 April 2020

Greenpeace (2020) CHOPPY WATERS Forced Labour and Illegal Fishing in Taiwan's Distant Water Fisheries www.greenpeace.org/southeastasia/publication/3690/choppy-waters-forced-labour-and-illegal-fishing-in-taiwansdistant-water-fisheries/ Accessed 12 August 2020Guinot G, Cavin L (2016) 'Fish' (Actinopterygii and Elasmobranchii) diversification patterns through deep time. Biol. Rev. 91:950-981.

Hanich Q, Davis R, Holmes G, Amidjogbe ER, Campbell B (2019) Drifting Fish Aggregating Devices (FADs) Deploying, Soaking and Setting - When Is a FAD 'Fishing'? International Journal of Marine and Coastal Law. 1-24. $10.1163 / 15718085-23441103$ 
Hareide NR, Carlson J, Clarke M, Clarke S, Ellis J, Fordham S, Fowler S, Pinho M, Raymakers C, Serena F, Seret B, Polti S (2008) European shark fisheries: a preliminary investigation into fisheries, conversion factors, trade products, markets and management measures. European Elasmobranch Association. IOTC-2008-WPEB-INF04 www.iotc.org/documents/european-shark-fisheries-preliminary-investigation-fisheries-conversion-factors-trade

Harrington JM, Myers RA, Rosenberg AA (2005) Wasted fishery resources: discarded bycatch in the USA. Fish and Fisheries. 6:350-61.

Heithaus MR, Frid A, Wirsing AJ, Dill LM, Fourqurean JW, Burkholder D, Thomson J, Bejder, L (2007) Statedependent risk-taking by green sea turtles mediates top-down effects of tiger shark intimidation in a marine ecosystem. Journal of Animal Ecology 6:837-844 doi.org/10.1111/j.1365-2656.2007.01260.x

Heithaus MR, Frid A, Wirsing AJ, Worm B (2008) Predicting ecological consequences of marine top predator declines. Trends in Ecology \& Evolution. 23(4):202-210.

Hilborn R, Walters CJ (1992) Quantitative fisheries stock assessment, choice, dynamics and uncertainty. Chapman and Hall, London. doi.org/10.1007/978-1-4615-3598-0

Hobbs CAD, Potts RWA, Bjerregaard WM, et al. Using DNA Barcoding to Investigate Patterns of Species Utilisation in UK Shark Products Reveals Threatened Species on Sale. Sci Rep 9, 1028 (2019). doi.org/10.1038/s41598-018$38270-3$

Human Rights at Sea (2020) Fisheries Observer Deaths at Sea, Human Rights and the Role and Responsibilities of Fisheries Organisations www.humanrightsatsea.org/2020/07/03/report-fisheries-observer-deaths-at-sea-human-rightsand-the-role-and-responsibilities-of-fisheries-organisations/ Accessed August 122020

Hutchinson MR, Itano D, Muir JA, Holland KN. (2015) Post-release survival of juvenile silky sharks in the tropical tuna purse seine fishery. Marine Ecology Progress Series, Vol. 521, pp. 143- 154

ICCAT (2019) International Commission for the Conservation of Atlantic Tunas Report of the Standing Committee on Research and Statistics (SCRS) Madrid, Spain, 30 September to 4 October 2019

www.iccat.int/Documents/Meetings/Docs/2019/REPORTS/2019_SCRS_ENG.pdf Accessed 22 April 2020

IPBES (2019): Global assessment report on biodiversity and ecosystem services of the Intergovernmental SciencePolicy Platform on Biodiversity and Ecosystem Services. E. S. IPBES secretariat, Bonn, Germany.

IUCN Red List www.iucnredlist.org Accessed 24 April 2020

Jones JB (1992) Environmental impact of trawling on the seabed: a review. New Zealand Journal of Marine and Freshwater Research. 26(1):59-67 doi.org/10.1080/00288330.1992.9516500

Kaplan IC, Cox SP, Kitchell JF (2007) Circle hooks for Pacific longliners: not a panacea for marlin and shark bycatch, but part of the solution. Trans. Am. Fish. Soc. 136:392-401. doi:10.1577/T05-301.1.

Kao E (2017) Hong Kong shark fin traders 'will be hit hard' by proposal to protect blue sharks. South China Morning Post. www.scmp.com/news/hong-kong/ health-environment/article/2108502/ hong-kong-shark-fin-traders-will-be-hithard Accessed 14 April 2020

Kearns M (2015) IPNLF: Tuna fishery certification 'fatally flawed.' Seafood Source www.seafoodsource.com/news/environment-sustainability/ipnlf-tuna-fishery-certification-fatally-flawed Accessed 24 April 2020

Kowacki EB (2018) Can dogfish save Cape Cod Fisheries? Christian Science Monitor www.csmonitor.com/Environment/2018/0820/Can-dogfish-save-Cape-Cod-fisheries Accessed 27 April 2020

Kriwet J, Benton MJ (2004) Neoselachian (chondrichthyes, Elasmobranchii) diversity across the cretaceous-tertiary boundary. Palaeogeogr. Palaeoclimatol. Palaeoecol. 214:181-194

Kriwet J, Kiessling W, Klug S (2009) Diversification trajectories and evolutionary life-history traits in early sharks and batoids. Proc. R. Soc. B 276 945-951 
Lam VYY, Sadovy de Mitcheson Y (2011) The sharks of South East Asia - unknown, unmonitored and unmanaged. Fish and Fisheries 12:51-74. doi.org/10.1111/j.1467-2979.2010.00383.X

Lorenz K (1963) Das Sogenannte Böse, Zur Naturgeschichte der Aggression. Verlag Dr Borotha-Schoeler, Vienna, Austria

MacNeil MA, Chapman DD, Heupel M. et al. (2020) Global status and conservation potential of reef sharks. Nature. doi.org/10.1038/s41586-020-2519-y

Maine Seafood Guide, University of Maine. seagrant.umaine.edu/maine-seafood-guide Accessed 14 April 2020

Marine Stewardship Council (2018) Critical requirements necessary to improve marine stewardship council principle awionline.org/sites/default/files/uploads/documents/temp/AWI-ML-Open-Letter-to-MSC-012018.pdf Accessed August 122020

Marine Stewardship Council (2020) US spiny dogfish and winter skate. fisheries.msc.org/en/fisheries/us-atlantic-spinydogfish-and-winter-skate/ Accessed 24 April 2020

Marine Stewardship Council (2020) Echebastar Indian Ocean purse seine skipjack tuna. fisheries.msc.org/en/fisheries/echebastar-indian-ocean-purse-seine-skipjack-tuna

Mason F. (2002) The Newfoundland Cod Stock Collapse: A Review and Analysis of Social Factors. Electronic Green Journal, UCLA https://escholarship.org/uc/item/19p7z78s

McVeighand K, Firdaus F. (2020) 'Hold on Brother': final days of doomed crew on Chinese shark finning boat. The Guardian 7 July 2020 www.theguardian.com/environment/2020/jul/07/hold-on-brother-final-days-of-doomed-crew-onchinese-shark-finning-boat Accessed 12 August 2020

Mourier J, Vercelloni J, Planes S. (2012). Evidence of social communities in a spatially structured network of a freeranging shark species. Animal Behaviour, 83(2), 389-401.

Mumby PJ, Dahlgren CP, Harborne AR, Kappel CV, Micheli F, Brumbaugh DR, Holmes KE, Mendes JM, Broad K, Sanchirico JN, Buch K, Box S, Stoffle RW, Andrew B. Gill AB. Fishing, Trophic Cascades, and the Process of Grazing on Coral Reefs Science : 98-101. science.sciencemag.org/content/311/5757/98

Musick, J.A.; Musick, S. (2011) Sharks. FAO Fisheries and Aquaculture Reviews and Studies. Rome, FAO 13p.

Myers RA, Worm B (2003) Rapid worldwide depletion of predatory fish communities. Nature. 423(6937):280-3. doi.org/10.1038/nature01610

Myers RA, Baum JK, Shepherd TD, Powers SP, Peterson CH (2007) Cascading Effects of the Loss of Apex Predatory Sharks from a Coastal Ocean Science. 423(6937):280-3 doi.org/10.1126/science.1138657

New York Post (2016) Fish sticks for millennials! Seafood industry rebrands 'trash fish'. nypost.com/2016/01/21/thenew-fish-sticks-for-millennials Accessed 22 April 2020

NOAA Fisheries (2017) Shark Finning Report to Congress. repository.library.noaa.gov/view/noaa/17060 Accessed 14 April 2020

NOAA Fisheries (2020) Atlantic Shortfin Mako Shark. www.fisheries.noaa.gov/species/atlantic-shortfin-mako-shark Accessed 6 May 2020

NOAA Fisheries (2020) Atlantic Spiny Dogfish. www.fisheries.noaa.gov/species/atlantic-spiny-dogfish: Accessed 6 May 2020

Norse EA, Brooke S, Cheung WWL, Clark MR, Ekeland I, Froese R, Gjerde KM, Haedrich RL, Heppell SS, Morato T, Morgan LE, Pauly D, Sumaila R, Watson, R (2011) Sustainability of deep-sea fisheries. Marine Policy. 36(2)307-320 doi.org/10.1016/j.marpol.2011.06.008

O’Leary BC, Winther-Janson M, Bainbridge JM, Aitken J, Hawkins JP, Roberts CM (2016) Effective Coverage Targets for Ocean Protection. Conservation Letters 9: 398-404 doi.org/10.1111/conl.12247 
Okes N, Sant G (2019) An overview of major shark traders, catchers and species. TRAFFIC, Cambridge, UK.

Okey TA, Banks S, Born AF, Bustamante RH, Calvopiña M, Edgar GJ, Espinoza E José MiguelFariña J, Garske LE, Reck GK Salazar S, Shepherd S, Toral-Granda V, Wallem P (2004) A trophic model of a Galápagos subtidal rocky reef for evaluating fisheries and conservation strategies. Ecol. Model.172:383-401

Oliver S, Braccini M, Newman SJ, Harvey ES (2015) Global patterns in the bycatch of sharks and rays. Marine Policy 54:86-97. doi.org/ 10.1016/j.marpol.2014.12.017

Papastamatiou YP, Bodey TW, Caselle JE, Bradley D, Freeman R, Friedlander AM. Jacoby DMP. (2020) Multiyear social stability and social information use in reef sharks with diel fission-fusion dynamics Proc. R. Soc. B.28720201063http://doi.org/10.1098/rspb.2020.1063

Pauly D, Zeller D (2016) Catch reconstructions reveal that global marine fisheries catches are higher than reported and declining. Nat. Commun 710244 doi.org/10.1038/ncomms10244

Poisson F, Filmalter JD, Vernet AL, Dagorn L, (2014) Mortality rate of silky sharks (Carcharhinus falciformis) caught in the tropical tuna purse seine fishery in the Indian Ocean. Can. J. Fish. Aquat. Sci. 71, 1-4.

Porcher IF (2010) The Shark Sessions My Sunset Rendezvous. Strategic Book Publishing, Traverse City, Michigan, USA

Porcher IF (2017) The True Nature of Sharks. Independent. USA

Porcher IF, Darvell BW, Cuny G (2019) Response to "A United States shark fin ban would undermine sustainable shark fisheries” D.S. Shiffman \& R.E. Hueter, Marine Policy 85 (2017) 138-140. Marine Policy. 104:85-89

doi.org/10.1016/j.marpol.2019.02.058

Queiroz N, Humphries N, Couto A, Vedor M, da Costa I, Sequeira A, Mucientes G, Santos A, Abascal F, Abercrombie D, Abrantes K, Acuña-Marrero D, Afonso A, Afonso P, Anders D, Araujo G, Arauz R, Bach P, Barnett A, Sims D (2019). Global spatial risk assessment of sharks under the footprint of fisheries. Nature. 572. 1. 10.1038/s41586-0191444-4.

Rago PJ, Sosebee KA, Brodziak JK, Murawski SA, Anderson ED (1998) Implications of recent increases in catches on the dynamics of Northwest Atlantic spiny dogfish (Squalus acanthias). doi.org/10.1016/S0165-7836(98)00181-7

Reid DG, Graham N, Suuronen P, He P, Pol M. (2016). Implementing balanced harvesting: practical challenges and other implications. ICES J. Mar. Sci. 73:1690-1696. doi: 10.1093/icesjms/fsv253

Rigby CL, Barreto R, Carlson J, Fernando D, Fordham S, Francis MP, Jabado RW, Liu KM, Marshall A, Pacoureau N, Romanov E, Sherley RB, Winker H (2019) Isurus oxyrinchus The IUCN Red List of Threatened Species 2019: e.T39341A2903170. doi.org/10.2305/IUCN.UK.2019-1.RLTS.T39341A2903170.en

Sadovy de Mitcheson Y, Andersson AA, Hofford A, Law CSW, Hau LCY, Pauly D (2018) Out of control means off the menu: The case for ceasing consumption of luxury products from highly vulnerable species when international trade cannot be adequately controlled; shark fin as a case study. Marine Policy 98:115-120.

doi.org/10.1016/j.marpol.2018.08.012

Sala E, Mayorga J, Costello C, Kroodsma D, Palomares MLD, Pauly D, Sumaila UR, Zeller D (2018) The economics of fishing the high seas. Science Advances 4(6) doi.org/10.1126/sciadv.aat2504

Sea Shepherd (2017) Operation Sola Stella: Combatting Illegal Fishing in Liberia, West Africa https://seashepherd.org/campaigns/iuu-fishing-africa/iuu-campaigns/sola-stella/ Accessed 22 August 2020

Sea Shepherd (2017) Arrest of poaching vessel shows shark liver oil production could drive species to extinction. https://www.seashepherdglobal.org/latest-news/shark-liver-oil-labiko2/

Shiffman DS, Hueter RE (2017) A United States shark fin ban would undermine sustainable shark fisheries. Mar. Pol. $85: 138-140$.

Simpfendorfer CA, Dulvy NK (2017) Bright spots of sustainable shark fishing. Curr. Biol. 27: R97-R98. 
St. Gelais AT, Costa-Pierce BA (2016) Mercury concentrations in Northwest Atlantic winter-caught, male spiny dogfish (Squalus acanthias): A geographic mercury comparison and risk-reward framework for human consumption. Marine Pollution Bulletin, 102(1):199-205. doi.org/10.1016/j.marpolbul.2015.12.009

Stevens JD, Bonfil R, Dulvy NK, Walker PA (2000) The effects of fishing on sharks, rays, and chimaeras (chondrichthyans), and the implications for marine ecosystem. ICES J. Mar.Sci., 57, 476-494.

Sumaila U, Rashid K, Ahmed TL, Watson R, Tyedmers P, Pauly D (2010) Subsidies to high seas bottom trawl fleets and the sustainability of deep-sea demersal fish stocks. Marine Policy 34(3):495-497

doi.org/10.1016/j.marpol.2009.10.004

Sumaila RU, Ebrahim N, Schuhbauer A, Skerritt D, Li Y, Sik Kim H, Mallory TG, Lam VWL, Pauly D (2019) Updated estimates and analysis of global fisheries subsidies. Marine Policy. 109:103695

doi.org/10.1016/j.marpol.2019.103695.

Sumaila UR, Zeller D, Hood L, Palomares MLD, Li Y, Pauly D (2020) Illicit trade in marine fish catch and its effects on ecosystems and people worldwide. Sci Adv. Feb 26;6(9):eaaz3801. doi.org/ 10.1126/sciadv.aaz3801.

Taylor DL, Kutil NJ, Malek AJ, Collie JS (2014) Mercury bioaccumulation in cartilaginous fishes from southern new England coastal waters: contamination from a trophic ecology and human health perspective. Mar. Environ. Res. 99:2033Tsikliras AC, Froese R (2019) Maximum Sustainable Yield. in: Fath BD (ed) Encyclopedia of Ecology, 2nd ed., vol.1:108-115. Oxford: Elsevier.

Travis W (1961) Shark For Sale. Rand McNally Chicago

Travis J, Coleman FC, Auster PJ, Cury PM, Estes JA, Orensanz J, Peterson CH, Power ME, Steneck RS, Wootton TJ (2014) Species interactions and fisheries management. Proceedings of the National Academy of Sciences 111 (2) 581 584; DOI: 10.1073/pnas.1305853111

Vincent ACJ, Sadovy de Mitcheson Y, Fowler SL, Lieberman S (2013) The role of CITES in the conservation of marine fishes subject to international trade. Fish and Fisheries. 15: 563-592.

Walker TI (1998) Can shark resources be harvested sustainability? A question revisited with a review of shark fisheries. Mar. Freshw. Res. 49:553-572.

Wang Y, Zhou C, Xu L, Wan R, Shi J, Wang X, Tang H, Wang L, Yu W, Wang K, (2020) Degradability evaluation for natural material fibre used on fish aggregation devices (FADs) in tuna purse seine fishery, Aquaculture and Fisheries, doi.org/10.1016/j.aaf.2020.06.014.

Ward P, Myers RA (2005) Shifts in open-ocean fish communities coinciding with the commencement of commercial fishing. Ecology 86:835-847.

Ward-Paige CA, Keith DM, Worm B, Lotze HK (2012) Recovery potential and conservation options for elasmobranchs. Journal of Fish Biology 80:1844-1869 doi.org/10.1111/j.1095-8649.2012.03246.x

Ward-Paige CA, (2017) A global overview of shark sanctuary regulations and their impact on shark fisheries. Marine Policy 82:87,97 doi.org/10.1016/j.marpol.2017.05.004

Wiersma, J, Carroll M (2018) An Economic Analysis of Spiny Dogfish: Historical Trends, Future Markets, and Implications for Management Action. Massachusetts Division of Marine Fisheries, Seafood Marketing Program. www.mass.gov/files/documents/2018/12/05/An Economic Analysis of Spiny Dogfish.pdf Accessed 14 April 2020

Witkin T, Dissanayake ST, McClenachan L (2015) Opportunities and barriers for fisheries diversification: Consumer choice in New England, Fisheries research 168:56-62.World Bank (2017) The Sunken Billions Revisited: Progress and Challenges in Global Marine Fisheries. Washington, DC: World Bank. Environment and Sustainable Development series. doi.org/10.1596/978-1-4648-0919-4

Worm B, Davis B, Kettemer L, Ward-Paige CA, Chapman D, Heithaus MR, Kessel ST, Gruber SH (2013) Global catches, exploitation rates, and rebuilding options for sharks. Marine Policy 40:194-204

doi.org/10.1016/j.marpol.2012.12.034. 
Ziegler I (2019) Shark Finning - a Case Study Highlighting the Lack of Best Practice and Application of a Risk Based Need for Data "Combating Shark Finning, an IUU fishing activity that severely undermines conservation efforts" Transparency and Monitoring to Combat IUU in MSC Certified Fisheries www.make-stewardship-count.org/wpcontent/uploads/2020/01/Iris-Ziegler-Discussion-Paper-Shark-Finning.pdf Accessed 12 August 2020

Zhou S, Kolding J, Garcia SM, et al. (2019) Balanced harvest: concept, policies, evidence, and management implications. Rev Fish Biol Fisheries 29:711-733 doi.org/10.1007/s11160-019-09568-w 